\title{
Cloning and transcriptional analysis of the nifUHDK genes of Trichodesmium sp. IMS101 reveals stable nifD, nifDK and nifK transcripts
}

\author{
Benny Dominic, Yi-Bu Chen and Jonathan P. Zehr \\ Author for correspondence: Jonathan P. Zehr. Tel: +1518 276 8386. Fax: +1 5182762162. \\ e-mail: zehrj@rpi.edu
}

Department of Biology, Rensselaer Polytechnic Institute, 110 8th St, Troy, NY 12180-3590, USA
Trichodesmium spp. are marine filamentous, non-heterocystous cyanobacteria capable of aerobic nitrogen fixation. In this study, the nitrogenase structural genes (nifHDK) and nifU gene of Trichodesmium sp. IMS101 were cloned and sequenced. The Trichodesmium sp. IMS101 nifH, nifD and nifK amino acid sequences showed only $79 \%, 66 \%$ and $68 \%$ identity, respectively, to those of Anabaena sp. strain PCC 7120. A potential transcription start site for nifH was found 212 bases upstream of the nifH start codon. Promoter-like nucleotide sequences upstream of the transcription start site were identified that were very similar to those identified for the nitrogenase genes of Anabaena spp. Sequence analysis revealed regions of DNA that may form stem-loop structures in the intercistronic regions downstream of nifH and nifD. RNA analysis by Northern hybridization revealed the presence of transcripts corresponding to nifH, nifHD and nifHDK. Surprisingly, Northern hybridization also revealed the presence of transcripts that corresponded to nifD, nifDK and nifK, which have not been previously reported as transcripts in contiguous nifHDK genes of cyanobacteria. Transcription of the nifHDK genes was not significantly repressed in the presence of nitrate at a final concentration of $20 \mathrm{mM}$ or at oxygen concentrations of up to $40 \%$, whereas ammonium and urea inhibited nifHDK transcription. The transcription of the nifHDK genes was not affected by darkness, which suggests that transcription of these genes in Trichodesmium is not directly regulated by light.

Keywords: cyanobacteria, Trichodesmium sp., nitrogen fixation, nifHDK gene expression, nifH promoters

\section{INTRODUCTION}

It is estimated that Trichodesmium, the most abundant free-living diazotroph of tropical and subtropical oceans (Carpenter \& Romans, 1991), contributes significantly to global nitrogen fixation (Michaels et al., 1996; Gallon et al., 1996; Capone et al., 1997). Interestingly, filamentous non-heterocystous marine cyanobacteria of the genus Trichodesmium present a paradox with respect to paradigms of regulation of nitrogen fixation in photosynthetic prokaryotes (Gallon et al., 1996). Nitrogenase, the enzyme that catalyses nitrogen fixation, is highly sensitive to inactivation by oxygen (Fay, 1992; Postgate, 1982). The most common mechanisms for protection in cyanobacterial diazotrophs are spatial and/or temporal

The GenBank accession numbers for the nucleotide sequences reported in this paper are AF016484 and AF055034. separation of oxygen-sensitive nitrogen fixation from oxygenic photosynthesis (Bergman et al., 1997; Gallon, 1992). By contrast, Trichodesmium has the unique ability to fix nitrogen aerobically while photosynthesizing, without any obvious separation of these two incompatible processes (Capone et al., 1997). Furthermore, Trichodesmium will only fix nitrogen during the day, apparently cued by a circadian rhythm (Chen $e$ t al., 1996). Recently, slow-growing cultures of Trichodesmium sp. IMS101, grown in defined liquid medium, have become available (Chen et al., 1996; PrufertBebout et al., 1993), which facilitates basic molecular biology investigations.

Nitrogenase is composed of the iron protein (dinitrogenase reductase) encoded by the nif $H$ gene, and the molybdenum iron protein (dinitrogenase) encoded by the nifDK genes. In many nitrogen-fixing microorganisms the nifHDK genes are contiguous. Known 
exceptions are Bradyrhizobium japonicum, Rhizobium sp. strain IRc 78 and Frankia strain FaC1 (AlvarezMorales et al., 1986; Ligon \& Nakas, 1987). In all the nitrogen-fixing non-heterocystous cyanobacteria examined, including Trichodesmium, the nif structural genes are contiguous (Bergman et al., 1997; Zehr et al., 1991). In the vegetative cells of the heterocystous cyanobacterium Anabaena sp. PCC 7120, the nifD gene is interrupted by an $11 \mathrm{~kb}$ DNA element that is excised and removed upon differentiation of nitrogen-fixing heterocystous cells, making the rearranged nifHDK genes contiguous (Golden et al., 1985). This rearranged nifHDK operon is transcribed from a promoter upstream of the $n i f H$ gene as a single transcriptional unit (Brusca et al., 1989; Golden et al., 1985, 1991; Haselkorn et al., 1986).

The nif genes in many non-cyanobacterial diazotrophs, including Klebsiella pneumoniae, are transcribed by an RNA polymerase that utilizes a sigma $(\sigma)$ factor known as $\mathrm{RpoN}$ or $\sigma^{54}$. The $\mathrm{RpoN}$-dependent promoters usually have a highly conserved $-24,-12$ sequence, instead of the consensus sequence located around positions -35 and -10 recognized by $\sigma^{70}$ and most other $\sigma$ factors (Merrick, 1992). Activation of nif promoters in many non-cyanobacterial diazotrophs is NifA dependent (Merrick, 1992). The nifA product is required for transcription of all nif operons (except $n i f(A)$ and the nif $L$ product turns off transcription of all nif operons other than nifLA, in response to oxygen and fixed nitrogen (Collins \& Brill, 1985; Roberts \& Brill, 1980). The nifA protein activates transcription by binding to the consensus DNA sequence TGT $\left(\mathrm{N}_{10}\right)$ ACA, which is also known as the upstream activator sequence (UAS) and is typically located between 80 and $150 \mathrm{bp}$ upstream of the transcription start site (Dixon et al., 1987; Merrick, 1992). The UAS is known to be orientation independent and positively influences transcription of genes located 2-4 kb upstream or downstream (Merrick, 1992). The transcription of the nifLA operon itself is under the control of a regulatory cascade involving the $n t r B$ and $n t r C$ gene products and the $P_{\text {II }}$ protein (Magasanik, 1988). Though the $\mathrm{P}_{\mathrm{II}}$ protein has been identified in cyanobacteria, investigations have failed to identify homologues for $n t r B, n t r C, r p o N$ and nifLA (Flores \& Herrero, 1994; Merrick, 1992; Tandeau de Marsac \& Houmard, 1993). However, the search for the global nitrogen regulator led to the identification of the $n t c A$ gene, which belongs to the crp gene family (Vega-Palas et al., 1990). Hence, the regulation of nif genes in cyanobacteria is thought to be under the control of the global nitrogen regulator $n t c A$ (Luque et al., 1994; Flores \& Herrero, 1994). In general, however, cyanobacterial nif operons for which the transcription start site $(\mathrm{s})$ have been characterized do not possess a consensus NtcA-binding site [GTA $\left(\mathrm{N}_{8}\right)$ TAC or TGT( $\left.\mathrm{N}_{9-10}\right)$ ACA] at the proposed -35 position (Flores \& Herrero, 1994; Vega-Palas et al., 1992) of the promoter or upstream of the transcription start site. It has also been documented that under nitrogen-fixing conditions $n t c A$ expression (at the trans- criptional level) was inversely proportional to nifHDK transcript abundance (Bradley \& Reddy, 1997).

In this study, the nifU and nifHDK genes of Trichodesmium sp. IMS101 (Chen et al., 1996; Prufert-Bebout et al., 1993) were cloned and sequenced to compare the nitrogenase proteins and nif regulatory region of Trichodesmium to other cyanobacterial diazotrophs. The nifHDK transcripts were also characterized, and expression of nifHDK in response to different nitrogen sources, oxygen concentration and light intensity was examined.

\section{METHODS}

Strains and growth conditions. Liquid cultures of Trichodesmium sp. IMS101 (Chen et al., 1996; Prufert-Bebout et al., 1993) were grown in YBCII medium (Chen et al., 1996) under a regular $12 \mathrm{~h}$ light $/ 12 \mathrm{~h}$ dark regime, at $26^{\circ} \mathrm{C}$. The $12 \mathrm{~h} \mathrm{light}$ regime is the subjective light phase which begins at 1000 and ends at $2200 \mathrm{~h}$. For ammonium, urea and nitrate experiments, cultures were transferred to YBCII medium supplemented with $2 \mathrm{mM} \mathrm{NH}_{4} \mathrm{Cl}, 2 \mathrm{mM}$ urea or $20 \mathrm{mM} \mathrm{NaNO}_{3}$, respectively, for $2 \mathrm{~h}$. For the light intensity experiment, YBCII medium-grown cultures were exposed to zero (complete darkness), 100 and $300 \mu \mathrm{E} \mathrm{m}^{-2} \mathrm{~s}^{-1}$ light intensity, respectively, for $3 \mathrm{~h}$. For the oxygen experiment, the head-space of each incubation flask was flushed and replaced with air containing oxygen at the indicated concentration $(20 \%, \mathrm{v} / \mathrm{v}$, in control; $40 \%, v / v$, or $80 \%, v / v$, in experiments) and the flasks were sealed. The duration of the oxygen experiment was $3 \mathrm{~h}$.

Cultures of Escherichia coli strain XL-1 Blue MRF' (Stratagene) were grown and/or maintained in liquid LB medium or on $\mathrm{LB}$ agar $(1.5 \% \mathrm{w} / \mathrm{v}$ Difco agar) containing $12.5 \mu \mathrm{g}$ tetracycline $\mathrm{ml}^{-1}$ at $37^{\circ} \mathrm{C}$.

DNA extraction and genomic library construction. Genomic DNA from Trichodesmium sp. IMS101 was extracted following the protocol of Zehr et al. (1991) and purified using caesium chloride density-gradient centrifugation (Sambrook et al., 1989). The genomic DNA was then subjected to Sau3AI partial restriction digestion, using standardized conditions to obtain a size distribution between 23 and $14 \mathrm{~kb}$. The partially digested DNA was cloned into Lambda GEM-11 vector (Promega) using the XhoI half-site strategy (Promega). The genomic library was amplified and screened for nif genes.

Screening of the library for nif genes. The $\lambda$ library plaques were lifted with Hybond-N membranes (Amersham). Membranes were denatured for $2 \mathrm{~min}$ in denaturation solution $(1.5 \mathrm{M} \mathrm{NaCl}$ and $0.5 \mathrm{M} \mathrm{NaOH}$ ), neutralized for $5 \mathrm{~min}$ in neutralization solution $(1.5 \mathrm{M} \mathrm{NaCl}$ and $0.5 \mathrm{M}$ Tris $/ \mathrm{HCl}$ $\mathrm{pH} \mathrm{8.0),} \mathrm{and} \mathrm{rinsed} \mathrm{for} 30 \mathrm{~s}$ in a solution of $0 \cdot 2 \mathrm{M} \mathrm{Tris} / \mathrm{HCl}$ $(\mathrm{pH} \mathrm{7.5)}$ and $2 \times$ SSC. The membranes were vacuum-dried for $90 \mathrm{~min}$ at $80^{\circ} \mathrm{C}$. A 359 bp nifH DNA fragment cloned from Trichodesmium sp. (Zehr \& McReynolds, 1989) was labelled with $\left[\alpha^{32} \mathrm{P}\right] \mathrm{dCTP}$, using the Decaprime kit (Ambion) following the manufacturer's protocols, and used to screen the library using standard protocols (Sambrook et al., 1989). A positive plaque was identified and purified by secondary and tertiary rounds of screening. The size of the insert in the recombinantphage clone containing the nifH gene was estimated to be approximately $13 \mathrm{~kb}$.

Subcloning. The recombinant phage clone was amplified by culturing on a large scale and recombinant DNA was extracted using a phage DNA extraction kit (Qiagen). Recombinant- 
Table 1. Plasmids containing Trichodesmium sp. IMS101 gene(s) used or reported in this study

The source of the $5 \cdot 1 \mathrm{~kb}$ insert for pBD5N is the $\lambda$-nif clone obtained by screening Trichodesmium IMS101 genomic library. The source of insert for pBD511, pBD52, pBD509 and pBD535 is the $5 \cdot 1 \mathrm{~kb}$ insert for pBD5N (see Methods). The locations of HindIII and SacI restriction sites are shown in Fig. 5(a).

\begin{tabular}{|lll|}
\hline Plasmid & \multicolumn{1}{c|}{ Properties } & \multicolumn{1}{c|}{ Reference } \\
\hline pBD5N & pUC18 containing $5 \cdot 1 \mathrm{~kb}$ insert in SacI site & This work \\
pBD511 & pUC18 containing $1 \cdot 1 \mathrm{~kb}$ insert in HindIII & This work \\
& site & \\
pBD52 & pUC18 containing $2 \mathrm{~kb}$ insert in HindIII site & This work \\
pBD509 & pUC18 containing $0 \cdot 9 \mathrm{~kb}$ insert in HindIII & This work \\
& site & This work \\
pBD535 & pUC18 containing $1 \cdot 1 \mathrm{~kb}$ insert between & HindIII and SacI site \\
& pGEM-T vector, $0 \cdot 7 \mathrm{~kb}$ insert obtained by & This work \\
pBDHU & PCR amplification & \\
& M13mp19 vector, 359 bp insert obtained by & Zehr \& McReynolds (1989) \\
pTR & PCR amplification \\
&
\end{tabular}

phage DNA insert fragments were obtained using the restriction enzymes SacI and HindIII (Promega), and the fragments purified after gel electrophoresis using a Qiaex II Gel Extraction kit (Qiagen). These DNA fragments were ligated to SacI-digested pUC18 and HindIII-digested pUC18, respectively, using T4 ligase (Promega) and standard conditions (Sambrook et al., 1989). E. coli strain XL1B-MRF' (Stratagene) was transformed with the ligation mixtures. Transformants were selected on LB agar plates with ampicillin $\left(100 \mu \mathrm{g}\right.$ ampicillin $\left.\mathrm{ml}^{-1}\right)$, X-Gal and IPTG. A $5 \cdot 1 \mathrm{~kb}$ SacI fragment was extracted from a gel and subcloned in the plasmid vector pUC18 (identified as pBD5N). Recombinantplasmid DNA was extracted from pBD5N, and HindIII fragments used to create four minor subclones (pBD511, pBD52, pBD509 and pBD535) (Table 1).

PCR amplification and cloning of the nifU gene. Since the $\lambda$ clone isolated from the genomic library did not contain DNA beyond 222 bp upstream of the nifH start codon, a PCR-based strategy was adopted to expedite cloning of the region upstream of $n i f H$. A 17 base long degenerate oligonucleotide primer, BDNU17, was synthesized based on the amino acid sequence VMGQEA. The primers BDNU17 [5' GT(GATC)ATGGG(GATC)CA(AG)GA(AG)GC $3^{\prime}$ ] and HPRO-17 were used as forward and reverse primers, respectively, in the PCR reaction. The PCR conditions were as described by Zehr \& McReynolds (1989) using Trichodesmium sp. IMS101 genomic DNA as template. A $0.7 \mathrm{~kb}$ DNA fragment was amplified using the degenerate nifU primer (BDNU17) and the Trichodesmium nifH upstream sequence-specific primer HPRO-17 (5' CAGCAACATTAGAGTGC $3^{\prime}$ ) complementary to +42 to +1 and -177 to -193 of the nif $H$ coding sequence. This DNA fragment was cloned in pGEM-T vector (Promega) and the plasmid identified as pBDHU.

DNA sequencing. The major subclone $\mathrm{pBD} 5 \mathrm{~N}$ was partially sequenced to determine orientation of the clone. The pBD5Nderived minor subclones (pBD511, pBD52, pBD509 and pBD535) and pBDHU were then used for subsequent complete sequencing of both DNA strands. The plasmids were sequenced by the primer walking method. The regions at all
HindIII restriction sites were sequenced on plasmid pBD5N to ensure correct orientation and completeness of sequence generated from the subclones. Sequencing was performed by the University of Maine DNA Sequencing Facility (Orono, USA).

RNA isolation and Northern blot analysis. Cells were harvested and lysed in a modified STET buffer (only $25 \mathrm{mM}$ EDTA and with $100 \mathrm{mM}$ DTT). STET buffer (Ausubel et al., 1990) contains $8 \%(\mathrm{w} / \mathrm{v})$ sucrose, $5 \%(\mathrm{v} / \mathrm{v})$ Triton $X-100$, $50 \mathrm{mM}$ EDTA and $50 \mathrm{mM}$ Tris $\mathrm{pH} 7$. The total lysate was extracted once with equal-volume low-pH (4.5) equilibrated phenol/chloroform $(1: 1, \mathrm{v} / \mathrm{v})$ followed by extraction with TE $\mathrm{pH} 8$ saturated phenol/chloroform. The supernatant was then extracted with an equal volume of chloroform. RNA was ethanol precipitated and resuspended in nuclease-free water. The RNA extracted from equivalent amounts of biomass $(1 \mu \mathrm{g}$ chlorophyll $a$ ) was loaded on $1 \%(\mathrm{w} / \mathrm{v})$ formaldehyde gel, transferred to a Nytran membrane (Schleicher \& Schuell), and Northern hybridization carried out essentially following the protocols in Ausubel et al. (1990). Probes specific to nifH and nifK genes were obtained by HindIII restriction and gel extraction of appropriate DNA fragments (as described previously) from pBD5N. A gel-purified, PCR-amplified 1050 bp nifD DNA fragment was used as the nifD-specific probe. PCR conditions were as described by Zehr \& McReynolds (1989) using pBD5N as template and the synthetic oligonucleotides $5^{\prime}$ GGTGGAGACAAAAAGCT $3^{\prime}$ and $5^{\prime}$ AGTTGGGCTATTGAGAG ${ }^{\prime}$ as the forward and reverse primers, respectively. The probes were labelled with $\left[\alpha^{32} \mathrm{P}\right]$ dCTP using the Decaprime kit (Ambion), following the manufacturer's suggestions. The same membrane was sequentially hybridized to the nif $K$, nif $H$ and nifD probes to characterize the transcripts, or only to the nif $H$ probe in the experiments to study nifHDK expression. Hybridizations were incubated overnight in hybridization solution containing $50 \%$ $(\mathrm{v} / \mathrm{v})$ formamide, $5 \times$ SSC, $0.1 \%$ SDS and sonicated denatured salmon sperm DNA $\left(100 \mu \mathrm{g} \mathrm{ml}^{-1}\right)$. Membranes were washed at room temperature twice in $2 \times \mathrm{SSC} / 0 \cdot 1 \%$ SDS solution and then twice in $1 \times \mathrm{SSC} / 0.1 \%$ SDS solution followed by two high-stringency washes at $65^{\circ} \mathrm{C}$ in $0.1 \times \mathrm{SSC} / 0.1 \%$ SDS 
solution. Each wash was performed for $10 \mathrm{~min}$. The probes were stripped between hybridizations by rinsing the membrane in boiling $0 \cdot 1 \times \mathrm{SSC}$ and $0 \cdot 1 \%$ SDS solution, at $42{ }^{\circ} \mathrm{C}$.

Primer extension analysis. To determine the nifH transcription start site, $25 \mu \mathrm{g}$ total RNA (free of contaminating DNA) was used for the template of a reverse transcription reaction using a synthetic oligonucleotide (PXT-1) primer (5' TAGCCATTGCAGCTAGAGTATTCTGAGAAGTAGTGGACTTAC $3^{\prime}$ ) complementary to nucleotide positions +79 to +37 of the nifH coding sequence. After hybridization, dNTPs minus dCTP $(2.5 \mu \mathrm{l}$ of a $0.5 \mathrm{mM}$ stock solution $), 25 \mu \mathrm{Ci}$ $\left(9 \cdot 25 \times 10^{5} \mathrm{~Bq}\right)\left[\alpha^{32} \mathrm{P}\right] \mathrm{dCTP}$, reaction buffer and AMV reverse transcriptase (Promega) were added at $42^{\circ} \mathrm{C}$ (the total reaction volume was adjusted to $25 \mu \mathrm{l})$. The reaction was stopped after $45 \mathrm{~min}$ by adding $0.4 \mathrm{vol}$. stop solution (USB Sequenase kit). The reaction products were heat-denatured and separated on a sequencing gel, followed by autoradiography. The primer extension experiments were repeated with primers PXT-2 (5' CTTACCGATACCACCTTTTCCGTAAAATGCAATCTGACGCAT 3') and HPRO-17 (5' CAGCAACATTAGAGTGC $3^{\prime}$ ) complementary to +42 to +1 and -177 to -193 of the nifH coding sequence, using the same reaction conditions. To determine the size of the extension product, dideoxynucleotide sequencing reactions were run on the same gel using the same primers and pBD5N as template. The sequencing reactions were performed using Sequenase, following the manufacturer's protocols (USB).

\section{RESULTS}

\section{DNA sequence analysis}

The nucleotide sequence of the nifH coding region reported by Sroga et al. (1996) for natural populations of Trichodesmium thiebautii was $95 \cdot 2 \%$ identical to the sequence reported in this study. The Trichodesmium sp. IMS101 nif $H$-deduced amino acid sequence of 296 amino acid residues has striking differences compared to the carboxy-terminus of the deduced 294 amino acid residues of the T. thiebautii nifH sequence (Sroga et al., 1996). The deduced amino acid sequences for the nif $H$, nifD and nifK genes were compared to those of other known diazotrophs (Table 2). The Trichodesmium sp. IMS101 nifH, nifD and nifK amino acid sequences were $79 \%, 66 \%$ and $68 \%$ identical, respectively, to those of Anabaena sp. PCC 7120 nifH, nifD and nifK. The nucleotide sequence of the Trichodesmium sp. IMS101 nifH upstream and nifHDK intergenic regions is given in Fig. 1. A putative ribosome-binding site with reasonable similarity to a cyanobacterial ribosome-binding site (Stricker et al., 1997; Thiel, 1993) was identified in front of the coding sequence of the nifH, nifD and nifK genes (Fig. 1). The nifUHDK genes are contiguous, indicating unidirectional transcription. The sequence, TGT $\left(\mathrm{N}_{10}\right)$ ACA, centred about 157 bases upstream of the nifH translational start codon (Fig. 1a), but downstream of the transcript start site, is identical to the consensusbinding sequence $\left[\mathrm{TGT}\left(\mathrm{N}_{10}\right) \mathrm{ACA}\right]$ for the product of nifA (Dixon et al., 1987; Merrick, 1992). There are regions of DNA sequence that may form stem-loop structures in the mRNA. One (Fig. 1b) sequence starts 22 bases beyond the stop codon (TAA) of nifH. This sequence is followed by eight ' $A$ ' residues. The other (Fig. 1c) possible stem-loop structure starts 95 bases beyond the stop codon of nifD.

\section{Transcription start site mapping}

The results of the three primer extension experiments indicated that a transcription start site for nifH is located 212 bases upstream of the nifH start codon (Fig.

Table 2. Comparison of Trichodesmium sp. IMS101 nifHDK deduced amino acid sequences with those of $T$. thiebautii (only nifH is available), Anabaena sp. strain PCC 7120, Azotobacter vinelandii, Clostridium pasteurianum, K. pneumoniae and Synechococcus sp. strain PCC 8801

\begin{tabular}{|lcc|}
\hline nif gene & GenBank accession no. & Percentage identity \\
\hline nifH (T. thiebautii) & $\mathrm{U} 23507$ & 90 \\
nifH (Anabaena sp. PCC 7120) & $\mathrm{P} 00457$ & 79 \\
nifH1 (A. vinelandii) & $\mathrm{P} 00459$ & 71 \\
nifH1 (C. pasteurianum) & $\mathrm{P} 00456$ & 65 \\
nifH (K. pneumoniae) & $\mathrm{P} 00458$ & 71 \\
nifH (Synechococcus sp. strain PCC 8801) & $\mathrm{U} 22146$ & 79 \\
nifD (Anabaena sp. PCC 7120) & $\mathrm{P} 00464$ & 66 \\
nifD (A. vinelandii) & $\mathrm{P} 07328$ & 66 \\
nifD (C. pasteurianum) & $\mathrm{P} 00647$ & 42 \\
nifD (K. pneumoniae) & $\mathrm{P} 00466$ & 67 \\
nifD (Synechococcus sp. strain PCC 8801) & $\mathrm{U} 22146$ & 75 \\
nifK (Anabaena sp. PCC 7120) & $\mathrm{P} 00468$ & 68 \\
nifK (A. vinelandii) & $\mathrm{P} 07329$ & 55 \\
nifK (C. pasteurianum) & $\mathrm{P} 11347$ & 41 \\
nifK (K. pneumoniae) & $\mathrm{P} 09772$ & 70 \\
nifK (Synechococcus sp. strain PCC 8801) & $\mathrm{U} 22146$ & 70 \\
\hline
\end{tabular}


(a)

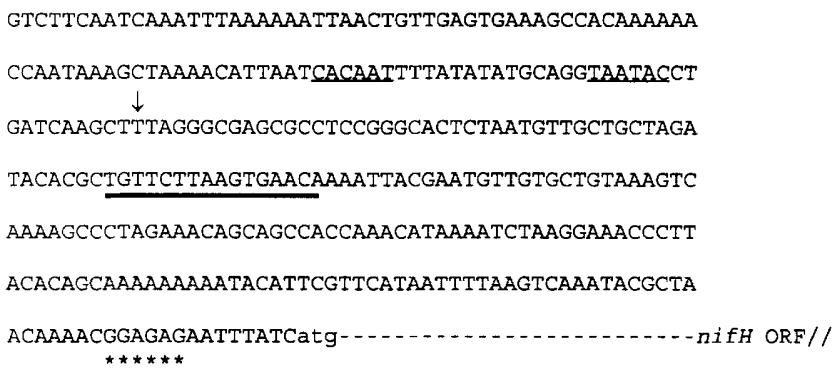

(b)

GCTTAAAATCTTTGAGCACAAA $\overline{\text { TTGGGGATGTACAAAATACACCCCATC }}$

TAAAAAAAACAATTAGTGATGAGTTTTTCTTAATTAATTTGTAGGGGTAG

ATTTTGTATATACTCAAAAGGTAACTGCCCCTATTAATACAAAACTCAAA

TACCAAAATATTCAAATATCCGAAGGAGATATGTAACatg-....--nifD ORF// $\star \star \star \star \star \star$

(c)

AACCAGCCGCTACGCGGAAGTTATAGATTTAAAAGTTAAAAGTTAAAAGT ATTAATTTAACCTTTTGGCTTTGAAGATCAATTTAGGAATGGAAATGGGG

TAATGCTATTATTGCTACGGCAACCCCAATACACAAACAAAAGATTTGAC TGGGAATTGGGAGTTAGAAGTTGTATTTCTTTCTTCCCCCTTCCTTCTGA

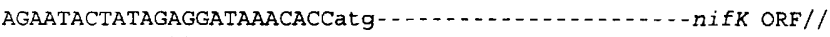

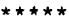

Fig. 1. Nucleotide sequences (a) upstream of the nifH translational start, (b) between nifH and nifD and (c) between nifD and nifK of Trichodesmium sp. IMS101. The translational start is indicated by lower case letters. The arrow $(\downarrow)$ indicates the transcription start site determined in this study. The presumed ribosome-binding sites are indicated by asterisks. The putative nifA-binding site-like sequence, TGT( $\left.N_{10}\right) A C A$, is indicated by a bold underline. The nucleotide sequences that may form stable stem-loop structures in the mRNA are shown in bold type and overlined. The putative -10 and -35 sequences are underlined.

2). There were additional bands in the primer extension reaction that corresponded to base positions closer to the nifH start codon. Although a few of the prominent bands could potentially be alternative transcription start sites, these are more likely due to RNA secondary structures that caused premature termination of the primer extension reactions. A putative -10 sequence (TAATAC) was located 11 bases upstream of the transcription start site and a putative -35 sequence (CACAAT) was located 31 bases upstream of the transcription start site (Fig. 3).

\section{Transcription of nifHDK operon/genes}

Transcription of the nifHDK genes in a transcriptionally active nitrogen-fixing culture of Trichodesmium sp. IMS101 was studied by Northern analysis. Total RNA from a mid-day Trichodesmium sp. IMS101 culture was hybridized with probes for nifH (BD511), nifD (BD1000), and nifK (BD509) (Fig. 4). The relative location of these probes is shown in Fig. 5(b). Hybridization with the nifH probe showed three distinct bands that correspond to approximately $1 \cdot 1,2 \cdot 8$ and $4 \cdot 5 \mathrm{~kb}$. The $1 \cdot 1 \mathrm{~kb}$ signal had the highest signal intensity and the nifH probe did not hybridize to any bands less than $1.1 \mathrm{~kb}$. The discrete bands indicate that sample RNA was of high quality with minimal degradation. Hybridization with the nifD probe showed four distinct bands that corresponded to approximately $2.8,3.4$ and $4.5 \mathrm{~kb}$ with varying signal intensity. The nif $D$ probe also hybridized and produced a slightly diffuse band centred at $1.7 \mathrm{~kb}$. Hybridization with the nifK probe showed two distinct bands that corresponded to 3.4 and $4.5 \mathrm{~kb}$ and a slightly diffuse band centred at $1.7 \mathrm{~kb}$, which is very similar to that observed with the nifD probe.

\section{Transcription of nifHDK in the presence of different nitrogen sources, and varying oxygen concentrations and light intensities}

Northern hybridization experiments revealed that the nifHDK transcript signal intensities on the autoradiogram decreased significantly after $2 \mathrm{~h}$ when the Trichodesmium culture medium contained $2 \mathrm{mM}$ $\mathrm{NH}_{4} \mathrm{Cl}$ or $2 \mathrm{mM}$ urea. It was also observed that the $\mathrm{NH}_{4} \mathrm{Cl}$ treatment led to the largest reduction in transcript signal intensity (Fig. 6b). Nitrogenase activity as measured by acetylene reduction also showed significantly lower values after $3 \mathrm{~h}$ treatment with the different nitrogen sources mentioned above and the lowest value for acetylene reduction was obtained from cultures treated with $\mathrm{NH}_{4} \mathrm{Cl}$ (data not shown). The decrease in nifHDK transcripts was minimal when the culture medium contained $20 \mathrm{mM} \mathrm{NaNO}$. When the Trichodesmium culture was exposed to air with $40 \%$ oxygen for $3 \mathrm{~h}$, the nifHDK transcript abundance (Fig. 6c) was approximately the same as the control. By contrast, at $80 \%$ oxygen concentration, nifHDK transcripts were absent (Fig. 6c) and acetylene reduction was low (data not shown). Exposure to complete darkness or $300 \mu \mathrm{E} \mathrm{m}^{-2} \mathrm{~s}^{-1}$ light intensity did not result in any significant change in nifHDK transcript abundance (Fig. 6a) when compared with that of the control culture maintained at a light intensity of $100 \mu \mathrm{E} \mathrm{m}^{-2} \mathrm{~s}^{-1}$.

\section{DISCUSSION}

The deduced amino acid sequences for the products of the nifH, nifD and nifK genes of Trichodesmium sp. IMS101 were found to have considerable identity to those of other known diazotrophs (Table 2), although the percentage identity varied significantly. Interestingly, it appears that the Trichodesmium sp. IMS101 NifD and NifK sequences have higher percentage identity to the NifD and NifK sequences of unicellular cyanobacteria than to the NifD and NifK sequences of filamentous heterocystous cyanobacteria.

The amino acid sequence VMGQEA is conserved in the nifU deduced amino acid sequences of $K$. pneumoniae, Anabaena sp., Anabaena azollae, Nostoc commune, Cyanothece sp. PCC 8801 and Plectonema boryanum (GenBank accession numbers: 128319, J05111, L34879, 
(a)

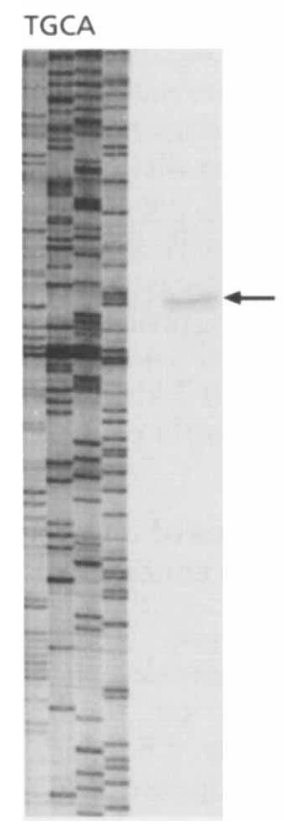

(b)

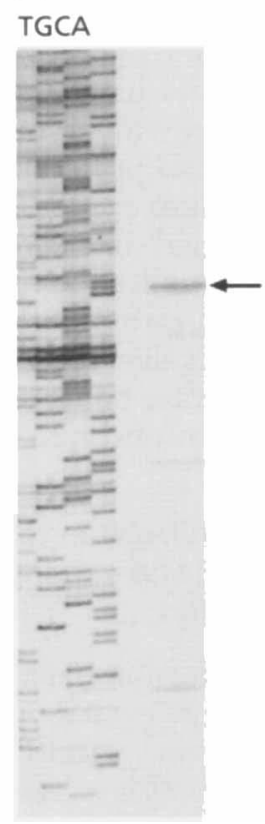

(c)

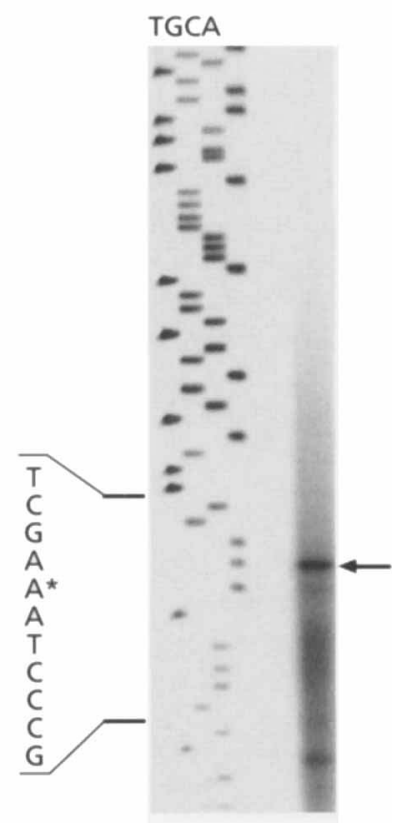

Fig. 2. Primer extension analysis of the 5 end of the Trichodesmium sp. IMS101 nifH transcript. Panels (a), (b) and (c) show autoradiograms of the reverse transcriptase products using primers PXT-1, PXT-2 and HPRO-17, respectively. Lanes A, C, G and T show the dideoxynucleotide sequencing ladder generated using the same primers and pBD5N DNA as template. The uppermost (longest) primer extension product (indicated by an arrow) corresponded to the same nucleotide (A), indicated by an asterisk, for all three primers.

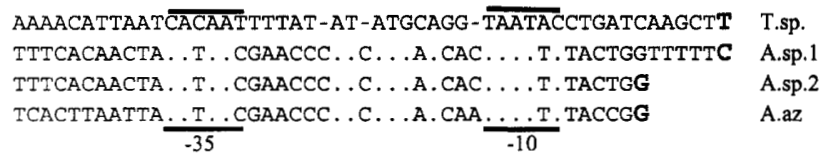

Fig. 3. Alignment of nif gene sequences upstream of the transcription start site. Letters in bold indicate the transcription start site. T.sp., nifH of Trichodesmium sp. IMS101 (this work); A.sp.1, nifH of Anabaena sp. strain PCC 7120 (Mulligan \& Haselkorn, 1989); A.sp.2, nifH of Anabaena sp. strain PCC 7120 (Haselkorn et al., 1983); A.az, nifH of Anabaena azollae (Jackman \& Mulligan, 1995). The consensus -10 and -35 promoter elements are indicated by bold lines. The dashes $(-)$ indicate gaps introduced in the sequence for the purpose of alignment, and periods (.) denote identity to the Trichodesmium sp. IMS101 sequence.
Fig. 4. Transcription of the nifHDK operon in Trichodesmium sp. IMS101. Northern blot of RNA obtained from an actively nitrogen-fixing Trichodesmium culture, probed with DNA probes for (a) nifH, (b) nifD and (c) nifk. The nifH probe hybridized to three bands corresponding to $1.1 \mathrm{~kb}(H), 2.8 \mathrm{~kb}$ $(H D)$ and $4.5 \mathrm{~kb}(H D K)$ transcripts. The nifD probe produced a diffuse band centred at $1.7 \mathrm{~kb}(D)$, and discrete bands corresponding to $2.8 \mathrm{~kb}(H D), 3.4 \mathrm{~kb}(D K)$ and $4.5 \mathrm{~kb}(H D K)$ transcripts. The nifK probe also produced a diffuse band centred at $1.7 \mathrm{~kb}(K)$, and discrete bands corresponding to $3.4 \mathrm{~kb}(D K)$ and $4.5 \mathrm{~kb}(H D K)$ transcripts.
L23514, AF001780, D00666). Moreover, the nif $U$ gene is located directly upstream of nifH in all cyanobacterial species for which the gene arrangement is known. Using the degenerate nifU primer, BDNU17, and the nifH upstream-sequence-specific primer, HPRO-17, part of the nif $U$ gene was amplified. The sequence of the $0.7 \mathrm{~kb}$ insert of pBDHU overlapped with that of the $5.1 \mathrm{~kb}$ insert of pBD5N by 45 bases. Therefore, the nif $U$ gene is located directly upstream of $n i f H$.

The transcription start site identified was located 212 bases upstream of the nifH translational start (Fig. 2). Therefore, Trichodesmium nifH mRNA has a long untranslated nifH leader sequence compared to other cyanobacterial nifH leaders (Haselkorn et al., 1983; Jackman \& Mulligan, 1995). The leader sequence and the nif $H$ coding region span $1.1 \mathrm{~kb}$, which is in agreement with the $1.1 \mathrm{~kb}$ band detected with the nifH probe (Fig. 4). The transcription start sites and promoter elements of cyanobacterial (Anabaena spp.) nifH genes are still not defined. Anabaena sp. PCC 7120 and A. azollae have almost identical sequences upstream of nifH as shown in Fig. 3 (Jackman \& Mulligan, 1995; Mulligan \& Haselkorn, 1989) but the proposed transcription start sites differ by at least six bases (Tumer $e t$ al., 1983; Haselkorn et al., 1983; Mulligan \& Haselkorn, 1989; Jackman \& Mulligan, 1995). Significant identities were observed between the sequence ${ }_{-17}$ TAATAC $_{-12}$ for Trichodesmium sp. IMS101 and the ${ }_{-17}$ TAATTC $_{-12}$ for Anabaena sp. PCC 7120, since the ' C' (of A.sp.1, Fig. 3) is considered to be the transcription start site as reported by Mulligan \& Haselkorn (1989). The sequence TAATTC is also present in A. azollae (Fig. 3). The sequence TAATCT was identified to be the -10 promoter element of the vnfD gene of Anabaena variabilis (Thiel, 
(a)

$$
1 \mathrm{~kb}
$$
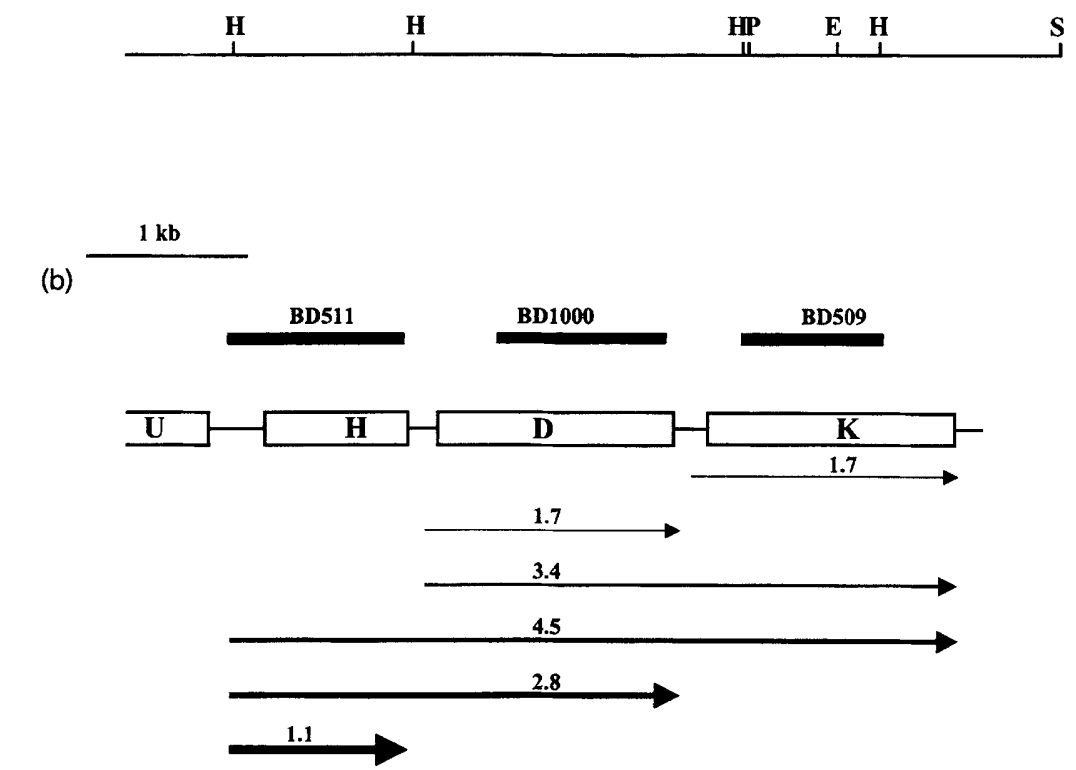

Fig. 5. The cloned nifUHDK region of Trichodesmium sp. IMS101. (a) Restriction site map of the cloned $5.8 \mathrm{~kb}$ nifUHDK region. E, EcoRI; H, HindIII; P, Pstl; S, Sacl. (b) Physical map of the nifUHDK genes. The open reading frames of nifU, $H, D$ and $K$ genes are shown as open rectangles. The DNA fragments (BD511, BD1000 and BD509) used as nifH, nifD and nifk probes, respectively, are shown as labelled bars. Stable transcripts (as deduced from Northern blot experiments) are drawn as horizontal arrows, with the thickness of the arrow reflecting the relative abundance of the transcripts, the number above the arrow indicating the estimated size of the transcript in $\mathrm{kb}$ and arrow head indicating the $3^{\prime}$ end of transcript.

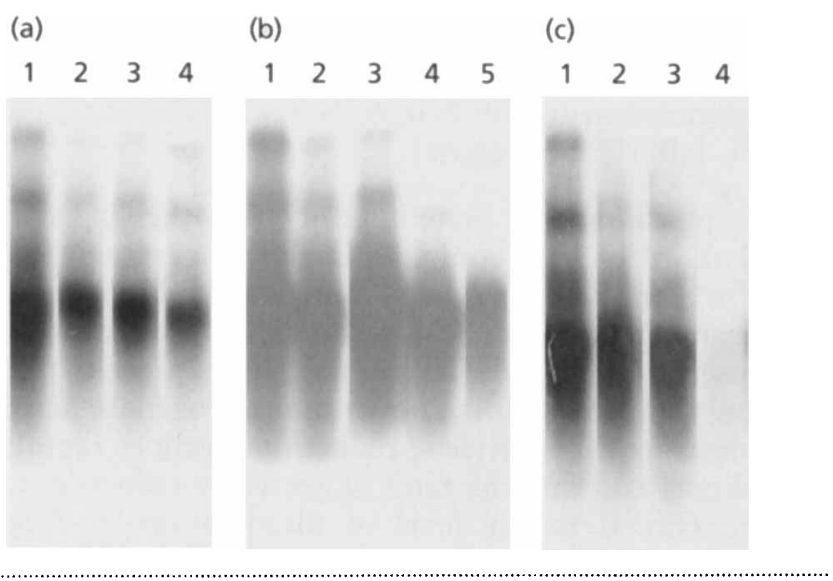

Fig. 6. Transcription of nifHDK genes as a function of light, nitrogen source and oxygen level. (a) Light experiment. Lane 1 , zero time point 1200; lane 2, control $\left(100 \mu \mathrm{E} \mathrm{m}^{-2} \mathrm{~s}^{-1}\right) 1500$; lane 3 , high light $\left(300 \mu \mathrm{E} \mathrm{m}^{-2} \mathrm{~s}^{-1}\right) 1500$; lane 4, darkness 1500 . (b) Nitrogen treatment experiment. Lane 1, zero time point 1200; lane 2, control 1400; lane 3, nitrate $(20 \mathrm{mM}) 1400$; lane 4, urea (2 mM) 1400; lane 5, ammonium (2 mM) 1400. (c) Oxygen experiment. Lane 1, zero time point 1200; lane 2, control 1500; lane 3, 40\% (v/v) oxygen 1500; lane 4, 80\% (v/v) oxygen 1500 . (Note: 1200,1400 and 1500 denote time points on a $24 \mathrm{~h}$ clock with $12 \mathrm{~h}$ light and $12 \mathrm{~h}$ dark phases; the subjective light phase was from 1000 to $2200 \mathrm{~h}$.)

1993). It should be noted that the conserved TAAT part of the -10 promoter element reported here is part of the proposed -10 promoter element of Anabaena sp. PCC 7120 (ACTAAT; Haselkorn et al., 1983). A -35 promoter-element-like sequence CACAAT was identified in Trichodesmium sp. IMS101 (Fig. 3) based on sequence similarity to the -35 sequence (CATAAC) reported for Anabaena sp. PCC 7120 (Tumer et al., 1983).

Multiple transcripts could be explained as processed products of one primary transcript or as multiple primary transcripts. The Northern hybridization analysis of Trichodesmium mRNA using nifH, nifD and nifK probes (Fig. 4) revealed that each probe hybridized to at least three transcripts. The size of the bands hybridizing to the nifH probe $(1.1,2.8$ and $4.5 \mathrm{~kb})$ suggests that transcription is initiated upstream of nifH, producing transcripts corresponding to nifH, nifHD and nifHDK. The $4.5 \mathrm{~kb}$ band is the only hybridization signal that is common to the nifH, the nifD and nifK probes. The $4.5 \mathrm{~kb}$ nifHDK band is consistent with the suggestion that the nif operon is transcribed as a single unit (Golden et al., 1985, 1991; Haselkorn et al., 1986). The slightly diffuse $1.7 \mathrm{~kb}$ band observed with the nifD and nifK probes could possibly be nascent nifD transcripts extending into nifK, or could be nifD transcripts or nifK transcripts. The hybridization signal that corresponded to the $1.7 \mathrm{~kb}$ transcript was not observed when the nifH probe was used and a $1.7 \mathrm{~kb}$ transcript is not large enough to be a nifHD $(2.8 \mathrm{~kb})$ transcript identified with both the nifH and the nifD probes. Hence, the $1.7 \mathrm{~kb}$ band must correspond to a transcript spanning the nifD region. Similarly, the nifK probe also hybridized to a $1.7 \mathrm{~kb}$ band that must correspond to a transcript spanning the nifK region. Since the nifK probe did not produce any hybridization signal at the $2 \cdot 8 \mathrm{~kb}$ nifHD region, the possibility that the nifK probe cross-hybridized to the $1.7 \mathrm{~kb}$ nifD transcripts can be eliminated. The nifD and nifK genes are very similar in size, making distinctions based on size of transcripts (as evidenced by 
the location of the hybridization signal) very difficult. It is likely that some of the nifD transcripts terminate between the nifD and the nifK coding regions. The nifK probe hybridizes to three transcripts, nifK $(1.7 \mathrm{~kb})$, nifDK $(3.4 \mathrm{~kb})$ and nifHDK $(4.5 \mathrm{~kb})$. The hybridization signals were not due to non-specific binding to $16 \mathrm{~S}$ or $23 \mathrm{~S}$ rRNA or other non-nif mRNA, since it was observed that RNA from non-nitrogen-fixing (sampled during the dark phase) cultures failed to give any signal for nif $H$, nifD or nifK probes (data not shown).

The other possible explanation for multiple transcripts is that these different transcripts are due to processing of the single $4.5 \mathrm{~kb}$ long nifHDK transcript. Processing of long mRNA by RNA-specific endonuclease(s) and exonuclease(s) has been described or suggested in E. coli and Rhodobacter capsulatus (Belasco et al., 1985; Heck et al., 1996; Peterson, 1992; Willison et al., 1993). In this study it was shown (Fig. 4) that there are significant amounts of stable nifHD, nifDK, nifD and nifK transcripts. The large amount of the $1.1 \mathrm{~kb}$ nifH mRNA indicates that there is no significant degradation of the mRNA by non-specific $5^{\prime} \rightarrow 3^{\prime}$ exonucleases. If the nifHDK transcripts were processed by cleavage at specific stem-loop sites and part of the nifHDK transcripts remained unprocessed, the observed pattern of transcripts (nifHDK, nifHD, nifDK, nif $H$, nifD and nifK) could result. However, such complex processing of transcripts is not usual and to our knowledge such processing machinery has not yet been reported in cyanobacteria. The different transcripts and the relative abundance of the transcripts of the Trichodesmium nifHDK genes are summarized in Fig. 5(b). To our knowledge, there has not been a transcription start site reported between nifH and nifD or nifD and nif $K$ in any diazotroph that has contiguously arranged nifHDK genes, although transcriptional regulation of internal promoters in operons has been documented in cyanobacteria. In the filamentous cyanobacteria Calothrix sp. strain PCC 7601, multiple transcripts were observed from different polycistronic units such as $a p c 1, c p c 1$ and cpc2 (Houmard et al., 1990; Mazel et al., 1988; Tandeau de Marsac et al., 1988).

The multiple nif transcripts are consistent with the presence of potential stem-loop structures that could terminate transcription downstream of $n i f H$ and nifD. Similar secondary structures with comparable energy values in the intercistronic regions of polycistronic transcription units have been shown to terminate transcription, even if not preventing read-through completely (Houmard, 1994). Hybridization to the nifH probe revealed significantly higher amounts of stable transcripts of nifH when compared with stable transcripts of nifHD and nifHDK (Fig. 4). The nifHD transcripts appeared to be more abundant than nifHDK transcripts. It is known that the Trichodesmium nifHDK transcription starts during early morning hours and stabilizes gradually towards mid-day (Chen et al., 1998; Wyman et al., 1996). The results indicate that transcripts that are initiated from the nif $H$ transcription start site do not all contain the complete nifHDK mRNA, and that the incomplete transcripts are not randomly terminated, but tend to contain only complete nifH or nifHD messages. This model is very similar to transcription of the gas vesicle genes (gvpA1A2C) of Calothrix sp. strain PCC 7601 (Csiszàr et al., 1987).

$\mathrm{NH}_{4} \mathrm{Cl}$ was the most effective of the three nitrogen sources in turning off transcription. Significant repression of nifHDK transcription was not observed even at high concentrations $(20 \mathrm{mM})$ of $\mathrm{NaNO}_{3}$. This observation is consistent with that of the filamentous nonheterocystous cyanobacterium, $P$. boryanum, where nitrogenase activity (as measured by acetylene reduction) is repressed or inhibited more rapidly by ammonium than by nitrate compounds (Rai et al., 1992). One of the reasons suggested for the lack of repression was the slow uptake of nitrate (Rai et al., 1992). However, transcription was not assayed in that study and the inhibition could have been due to posttranslational modification of nitrogenase protein.

Even after $3 \mathrm{~h}$ of exposure to $40 \%$ oxygen concentration there was no significant reduction in transcription of nifHDK genes of Trichodesmium sp. IMS101. Hence the decrease in nitrogenase activity above $\mathrm{pO}_{2}$ of 0.3 observed in Trichodesmium sp., could be due to posttranslational modification of nitrogenase protein (Ohki \& Fujita, 1988; Zehr et al., 1993). The results indicate that inhibition of nifHDK transcription occurs at oxygen concentration greater than $40 \%$ but less than or equal to $80 \%$ (after $3 \mathrm{~h}$ exposure).

Abrupt changes in light intensity (whether it be from $100 \mu \mathrm{E} \mathrm{m}^{-2} \mathrm{~s}^{-1}$ to complete darkness or from $100 \mu \mathrm{E}$ $\mathrm{m}^{-2} \mathrm{~s}^{-1}$ to $300 \mu \mathrm{E} \mathrm{m}^{-2} \mathrm{~s}^{-1}$ ) did not result in any significant change in nifHDK transcription, suggesting that transcription of nifHDK is not directly regulated by light. Conversely, it is known that nitrogenase activity, as measured by acetylene reduction, declines rapidly in darkness and that the rates of acetylene reduction were proportional to the level of illumination in Trichodesmium (Ohki \& Fujita, 1988).

Sequence analysis revealed regions of DNA that may form stem-loop structures in the intercistronic regions downstream of nifH and nifD and possible regulatory protein binding sites. Analysis of the transcription of nifHDK in Trichodesmium indicates several features in common with nifHDK transcription in other organisms. The sequences of the nifHDK genes are similar to other nifHDK sequences and there are striking similarities in the region upstream of the transcription start site of Trichodesmium sp. IMS101 and Anabaena spp. nifH genes. However, stable nifD, nifDK and nifK transcripts could be unique to Trichodesmium among cyanobacterial diazotrophs. The absence of a consensus NtcAbinding site upstream of the $n i f H$ transcription start site indicates that Trichodesmium sp. IMS101 nifHDK might not be directly regulated by NtcA. Further analysis of the regulation of nifHDK transcription in Trichodesmium might require the development of suitable mutants, which is not yet feasible. 


\section{ACKNOWLEDGEMENTS}

This research was supported by NSF (OCE 9503593, OCE 9202106) to J.P.Z. We thank M. Mellon for technical help and J. Collier for encouragement, for helpful suggestions and for reviewing the manuscript.

\section{REFERENCES}

Alvarez-Morales, A., Betancourt-Alvarez, M., Klauza, K. \& Hennecke, H. (1986). Activation of the Bradyrhizobium japonicum nifH and nifDK operons is dependent on promoter-upstream DNA sequence. Nucleic Acid Res 14, 4207-4227.

Ausubel, F. M., Brent, R., Kingston, R. E., Moore, D. D., Seidman, J. G., Smith, J. A. \& Struhl, K. (editors) (1990). Current Protocols in Molecular Biology. New York: Greene Publishing and Wiley Interscience.

Belasco, J. G., Beatty, J. T., Adams, C. W., von Gabain, A. \& Cohen, S. N. (1985). Differential expression of photosynthesis genes in $R$. capsulata results from segmental differences in stability within polycistronic rxcA transcript. Cell 40, 171-181.

Bergman, B., Gallon, J. R., Rai, A. N. \& Stal, L. J. (1997). Nitrogen fixation by non-heterocystous cyanobacteria. FEMS Microbiol Rev 19, 139-185.

Bradley, R. L. \& Reddy, K. J. (1997). Cloning, sequencing, and regulation of the global nitrogen regulator gene $n t c A$ in the unicellular diazotrophic cyanobacterium Cyanothece sp. strain BH68K. J. Bacteriol 179, 4407-4410.

Brusca, J. S., Hale, M. A., Carrasco, C. D. \& Golden, J. W. (1989). Excision of an 11-kilobase-pair DNA element from within the nifD gene in Anabaena variabilis heterocysts. J Bacteriol 171, 4138-4145.

Capone, G. C., Zehr, J. P., Pearl, H. W., Bergman, B. \& Carpenter, E. J. (1997). Trichodesmium, a globally significant marine cyanobacterium. Science 276, 1221-1229.

Carpenter, E. J. \& Romans, K. (1991). Major role of the cyanobacterium Trichodesmium in nutrient cycling in the North Atlantic Ocean. Science 254, 1356-1358.

Chen, Y., Zehr, J. P. \& Mellon, M. (1996). Growth and nitrogen fixation of the diazotrophic filamentous nonheterocystous cyanobacterium Trichodesmium sp. IMS101 in defined media : evidence for circadian rhythm. J Phycol 32, 916-923.

Chen, Y., Dominic, B., Mellon, M. \& Zehr, J. P. (1998). Circadian rhythm of nitrogenase gene expression in the diazotrophic filamentous nonheterocystous cyanobacterium Trichodesmium sp. IMS 101. J Bacteriol 180, 3598-3605.

Collins, J. J. \& Brill, W. J. (1985). Control of Klebsiella pneumoniae nif mRNA synthesis. J Bacteriol 162, 1186-1190.

Csiszàr, K., Houmard, J., Damerval, T. \& Tandeau de Marsac, N. (1987). Transcriptional analysis of the cyanobacterial gvpABC operon in differentiated cells: occurrence of an antisense RNA complementary to three overlapping transcripts. Gene 60, 29-37.

Dixon, R. A., Austin, S., Buck, M., Drummond, M., Hill, S., Holtel, A., MacFarlane, S., Merrick, M. \& Minchin, S. (1987). Genetics and regulation of nif and related genes in Klebsiella pneumoniae. Phil Trans $R$ Soc Lond B 317, 147-158.

Fay, P. (1992). Oxygen relations of nitrogen fixation in cyanobacteria. Microbiol Rev 56, 340-373.

Flores, E. \& Herrero, A. (1994). Assimilatory nitrogen metabolism and its regulation. In The Molecular Biology of Cyanobacteria, vol. 1, Advances in Photosynthesis, pp. 487-517. Edited by D. A. Bryant. Dordrecht: Kluwer.
Gallon, J. R. (1992). Tansley Review No. 44. Reconciling the incompatible: $\mathrm{N}_{2}$ fixation and $\mathrm{O}_{2}$. New Phytol 122, 571-609.

Gallon, J. R., Jones, D. A. \& Page, T. S. (1996). Trichodesmium, the paradoxical diazotroph. Algol Stud (Arch Hydrobiol) 83, 215243.

Golden, J. W., Robinson, S. J. \& Haselkorn, R. (1985). Rearrangement of nitrogen fixation genes during heterocyst differentiation in the cyanobacterium Anabaena. Nature 314, 419-423.

Golden, J. W., Whorff, L. L. \& Wiest, D. R. (1991). Independent regulation of nifHDK transcription and DNA rearrangement during heterocyst differentiation in the cyanobacterium Anabaena sp. strain PCC 7120. J Bacteriol 173, 7098-7105.

Haselkorn, R., Rice, D., Curtis, S. E. \& Robbinson, S. J. (1983). Organization and transcription of genes important in Anabaena heterocyst differentiation. Ann Microbiol 134B, 181-193.

Haselkorn, R., Golden, J. W., Lammers, P. J. \& Mulligan, M. E. (1986). Developmental rearrangement of cyanobacterial nitrogenfixation genes. Trends Genet 2, 255-259.

Heck, C., Rothfuchs, R., Jäger, A., Rauhut, R. \& Klug, G. (1996). Effect of $p u f Q-p u f B$ intercistronic region on $p u f$ mRNA stability in Rhodobacter capsulatus. Mol Microbiol 20, 1165-1178.

Houmard, J. (1994). Gene transcription in filamentous cyanobacteria. Microbiol 140, 433-441.

Houmard, J., Capuano, V., Colombano, M. V., Coursin, T. \& Tandeau de Marsac, N. (1990). Molecular characterization of the terminal energy acceptor of cyanobacterial phycobilisomes. Proc Natl Acad Sci USA 87, 2152-2156.

Jackman, D. M. \& Mulligan, M. E. (1995). Characterization of a nitrogen-fixation (nif) gene cluster from Anabaena azollae 1a shows that closely related cyanobacteria have highly variable but structured intergenic regions. Microbiol 141, 2235-2244.

Ligon, J. M. \& Nakas, J. P. (1987). Isolation and characterization of Frankia sp. strain $\mathrm{FaC1}$ genes involved in nitrogen fixation. Appl Environ Microbiol 53, 2321-2327.

Luque, I., Flores, E. \& Herrero, A. (1994). Molecular mechanism for the operation of nitrogen control in cyanobacteria. EMBO J $13,2862-2869$.

Magasanik, B. (1988). Reversible phosphorylation of an enhancer of an enhancer binding protein regulates the transcription of bacterial utilization genes. Trends Biochem $S_{c i}$ 12, 475-479.

Mazel, D., Houmard, J. \& Tandeau de Marsac, N. (1988). A multigene family in Calothrix sp. PCC 7601 encodes phycocyanin the major component of the cyanobacterial light harvesting antenna. Mol Gen Genet 211, 296-304.

Merrick, M. J. (1992). Regulation of nitrogen fixation genes in free-living and symbiotic bacteria. In Biological Nitrogen Fixation, pp. 835-876. Edited by G. Stacey, R. H. Burris \& H. J. Evans. New York: Chapman \& Hall.

Michaels, A. F., Olson, D., Sarmiento, J. L., Ammerman, J. W., Fanning, K., Jahnke, R., Knap, A. H., Lipshultz, F. \& Prospero, J. M. (1996). Inputs, losses and transformations of nitrogen and phosphorus in the pelagic North Atlantic Ocean. Biogeochemistry $35,181-226$.

Mulligan, M. E. \& Haselkorn, R. (1989). Nitrogen fixation (nif) genes of the cyanobacterium Anabaena species strain PCC 7120. J Biol Chem 264, 19200-19207.

Ohki, K. \& Fujita, Y. (1988). Aerobic nitrogenase activity measured as acetylene reduction in the marine cyanobacterium Trichodesmium spp. grown under artificial conditions. Marine Biol 98, 111-114.

Peterson, C. (1992). Control of functional mRNA stability in 
bacteria: multiple mechanisms of nucleolytic and non-nucleolytic inactivation. Mol Microbiol 6, 277-282.

Postgate, J. R. (1982). The Fundamentals of Nitrogen Fixation. Cambridge: Cambridge University Press.

Prufert-Bebout, L., Pearl, H. W. \& Lassen, C. (1993). Growth, nitrogen fixation, and spectral attenuation in cultivated Trichodesmium species. Appl Environ Microbiol 59, 1367-1375.

Rai, A. N., Borthakur, M. \& Bergman, B. (1992). Nitrogenase derepression, its regulation and metabolic changes associated with diazotrophy in the non-heterocystous cyanobacterium Plectonema boryanum PCC 73110. J Gen Microbiol 138, 481-491.

Roberts, G. P. \& Brill, W. J. (1980). Gene-product relationships of the nif regulon of Klebsiella pneumoniae. J Bacteriol 144, 210-216.

Sambrook, J., Fritsch, E. F. \& Maniatis, T. (1989). Molecular Cloning: a Laboratory Manual, 2nd edn. Cold Spring Harbor, NY: Cold Spring Harbor Laboratory.

Sroga, G. E., Landegren, U., Bergman, B. \& Lagerström-Fermér, M. (1996). Isolation of $n i f H$ and part of $n i f D$ by modified capture polymerase chain reaction from a natural population of the marine cyanobacterium Trichodesmium sp. FEMS Microbiol Lett 136, 137-145.

Stricker, O., Masepohl, B., Klipp, W. \& Böhme, H. (1997). Identification and characterization of the nif $\mathrm{V}$-nifZ-nifT gene region from the filamentous cyanobacterium Anabaena sp. strain PCC 7120. J Bacteriol 179, 2930-2937.

Tandeau de Marsac, N. \& Houmard, J. (1993). Adaptation of cyanobacteria to new environmental stimuli: new steps towards molecular mechanisms. FEMS Microbiol Rev 104, 119-190.

Tandeau de Marsac, N., Mazel, D., Damerval, T., Guglielmi, G., Capuano, V. \& Houmard, J. (1988). Photoregulation of gene expression in the filamentous cyanobacterium Calothrix sp. PCC 7601: light harvesting complexes and cell differentiation. Photosynth Res 18, 99-132.

Thiel, T. (1993). Characterization of genes for an alternative nitrogenase in the cyanobacterium Anabaena variabilis. $\mathrm{J} \mathrm{Bac-}$ teriol 175, 6276-6286.

Tumer, N. E., Robinson, S. J. \& Haselkorn, R. (1983). Different promoters for the Anabaena glutamine synthetase gene during growth using molecular or fixed nitrogen. Nature 306, 337-342.

Vega-Palas, M. A., Madeuno, F., Herrero, A. \& Flores, E. (1990). Identification and cloning of a regulatory gene for nitrogen assimilation in the cyanobacterium Synechococcus sp. strain PCC 7942. J Bacteriol 172, 643-647.

Vega-Palas, M. A., Flores, E. \& Herrero, A. (1992). NtcA, a global nitrogen regulator from the cyanobacterium Synechococcus that belongs to the Crp family of bacterial regulators. Mol Microbiol 6, 1853-1859.

Willison, J. C., Pierard, J. \& Hübner, P. (1993). Sequence and transcript analysis of the nitrogenase structural gene operon (nifHDK) of Rhodobacter capsulatus: evidence for intramolecular processing of nifHDK mRNA. Gene 133, 39-46.

Wyman, M., Zehr, J.P. \& Capone, D. G. (1996). Temporal variability in nitrogenase gene expression in natural population of the marine cyanobacterium Trichodesmium thiebautii. Appl Environ Microbiol 62, 1073-1075.

Zehr, J.P. \& McReynolds, L. A. (1989). Use of degenerate oligonucleotides for amplification of the nifH gene from the marine cyanobacterium Trichodesmium thiebautii. Appl Environ Microbiol 55, 2522-2526.

Zehr, J. P., Ohki, K. \& Fujita, Y. (1991). Arrangement of nitrogenase structural genes in an aerobic filamentous nonheterocystous cyanobacterium. J Bacteriol 173, 7055-7058.

Zehr, J. P., Wyman, M., Miller, V., Duguay, L. \& Capone, D. G. (1993). Modification of the Fe protein of nitrogenase in natural populations of Trichodesmium thiebautii. Appl Environ Microbiol 59, 669-676.

Received 6 April 1998; revised 10 July 1998; accepted 18 August 1998. 